\title{
Pengaruh Jenis Biochar dan Jenis Pupuk Organik terhadap Pertumbuhan dan Hasil Kacang Hijau (Vigna radiata. $\mathrm{L}$ )
}

\author{
Fransiskus Xaverius Mikel ${ }^{a}$ dan Eduardus Yosef Neonbeni ${ }^{b}$ \\ ${ }^{a}$ Fakultas Pertanian, Universitas Timor, Kefamenanu, TTU - NTT, Indonesia. \\ ${ }^{b}$ Fakultas Pertanian, Universitas Timor, Kefamenanu, TTU - NTT, Indonesia.
}

\section{Article Info}

Article history:

Received 20 September 2016

Received in revised form 22 Oktober 2016

Accepted 23 Januari 2017

\section{Keywords:}

Jenis Biochar

Jenis Pupuk Organik

Kacang Hijau

\begin{abstract}
Abstrak
Penelitian bertujuan untuk mengetahui pengaruh jenis biochar dan jenis pupuk organik terhadap pertumbuhan dan hasil kacang hijau (Vigna radiata, L.) serta mengetahui jenis biochar dan jenis pupuk pada pertumbuhan dan hasil kacang hijau, benih yang dipakai berasal dari sarana produksi pertanian terdekat yang bebas dari organisme pengganggu tanaman. Penelitian ini menggunakan rancangan acak lengkap (RAL) tiga faktorial yang diulang tiga kali. Faktor yang pertama terdiri dari tiga aras yaitu tanpa biochar, arang sekam padi, arang sebuk gergaji, faktor yang kedua terdiri dari tiga aras yaitu tanpa pupuk organik, pupuk kandang sapi dan pupuk guano. Penelitian dilaksanakan pada bulan Juni sampai dengan bulan Agustus 2016 di kebun percobaan Fakultas pertanian Universitas Timor, TTU, NTT.Hasil penelitian menunjukkan bahwa antara jenis biochar dan jenis pupuk organik tidak terjadi interaksi, baik pengaruhnya terhadap parameter pertumbuhan maupun hasil kacang hijau yang diamati. Biochar serbuk gergaji dan pupuk guano memberikan pengaruh paling optimal terhadap hasil tertinggi kacang hijau berupa berat biji, masing-masing seberat 2,60 g/tanaman dan 3,12 g/tanaman. (02017 dipublikasikan oleh Savana Cendana.
\end{abstract}

\section{Pendahuluan}

Kacang hijau (Vigna radiata, L.) merupakan tumbuhan hijau yang berasal dari India dan menyebar ke Indonesia kira-kira pada awal Abad ke 17. Tanaman ini berupa semak yang tumbuh tegak dan memiliki daya tahan dengan hawa kering serta dapat tumbuh pada kondisi tanah yang kurang subur, selain itu juga cara budidaya tanaman ini juga cukup mudah, tahan terhadap serangan Hama dan Penyakit. Tanaman ini juga merupakan sejenis palawija dan termasuk suku polong-polongan (Fabaceae) yang dikenal luas di daerah Tropika dan memiliki banyak manfaat dalam kehidupan sehari-hari, Kacang Hijau memiliki kandungan gizi yang cukup tinggi, antara lain karbohidrat $62,90 \mathrm{~g}$, protein $22,00 \mathrm{~g}$, lemak $1,20 \mathrm{~g}$, juga mengandung Vitamin A 157 , Vitamin B1 0,64 g, Vitamin C 6,00 g dan mineral Ca, P, Fe serta mengandung 345 kalori (Scan, 2012).

Tanaman ini tersebar hampir di seluruh daerah Indonesia namun hanya beberapa daerah yang menghasilkan kacang hijau dalam jumlah besar seperti daerah Sulawesi Selatan, Jawa Timur, Jawa Barat, Jawa Tengah, Nusa Tenggara barat, Nusa Tenggara Timur, dan Yogyakarta. Produksi kacang hijau di Indonesia pada tahun 2000 hanya 289.876 ton, sedangkan Tahun 2001 meningkat menjadi 301.000 ton, namun pada Tahun 2002 produksi menurun lagi menjadi 288.089 ton (BPS, 2003). Untuk daerah Sumatera Barat produktivitas kacang hijau pada tahun 2000 mencapai 1,14 ton/ha menurun menjadi 1,13 ton/ha pada tahun 2002 (Dinas Pertanian Sumatera Barat, 2003).

Hal ini menyebabkan kebutuhan kacang hijau mengalami peningkatan setiap tahun. Namun kebutuhan tersebut belum terpenuhi karena Produksinya masih rendah, sehingga kekurangan kebutuhan dipenuhi dengan cara mengimpor dari India, Filipina dan Thailand. Impor kacang hijau dari tahun 2002 sampai tahun 2012 mengalami peningkatan sebesar 16,53\%, sedangkan produksi kacang hijau mengalami peningkatan hanya $1,11 \%$ (Supeno dan Sujudi, 2004). Namun demikian, produksi kacang hijau di Indonesia masih rendah dan belum mampu memenuhi kebutuhan domestik. Nurjen et al. (2002) salah satu faktor penyebab rendahnya produksi kacang hijau adalah kurangnya unsur hara. Selain itu budidaya kacang hijau masih dijadikan sebagai tanaman sampingan sehingga belum dilakukan teknik budidaya yang optimal (Supeno dan Sujudi, 2004).

Biochar atau yang lebih kita kenal sebagai arang merupakan materi padat yang terbentuk dari karbonisasi biomasa. Biochar dapat ditambahkan ke tanah dengan tujuan untuk meningkatkan fungsi tanah dan mengurangi emisi dari biomasa yang secara alami terurai menjadi gas rumah kaca. biochar juga mempunyai fungsi untuk mengikat karbon cukup besar (IBI, 2012).

Biochar dapat dibuat dari berbagai bahan organik, seperti serbuk gergaji, sekam padi dan lain-lain. Menurut Bambang (2012), bahan baku pembuatan biochar umumnya adalah residu biomasa pertanian atau kehutanan, termasuk potongan kayu, tempurung kelapa, tandan kelapa sawit, tongkol jagung, sekam padi atau kulit buah kacang-kacangan, kulit-kulit kayu, sisa-sisa usaha perkayuan, serta bahan organik yang berasal dari sampah kertas, sampah kota dan kotoran hewan. Bila limbah tersebut mengalami pembakaran dalam keadaan Oksigen yang rendah atau tanpa Oksigen akan dihasilkan 3 substansi yaitu Metana dan Hidrogen yang dapat dijadikan bahan bakar, bio-oil yang dapat diperbaharui, dan arang hayati (Biochar) yang mempunyai sifat stabil dan kaya karbon $(>50 \%)$

Berdasarkan cara aplikasinya di lapangan, pupuk digolongkan menjadi dua jenis, yaitu pupuk akar dan pupuk daun. pupuk akar adalah pupuk yang diberikan pada tanaman melalui akar atau tanah. Sedangkan pupuk daun adalah pupuk yang diberikan pada tanaman melalui daun dengan cara disemprotkan. Antara pupuk akar dan pupuk daun masing-masing memiliki kelebihan dan kekurangan, komponen utama penyusun pupuk, pupuk dapat digolongkan menjadi dua jenis, yaitu pupuk organik dan pupuk anorganik. Pupuk organik adalah pupuk yang berasal dari tanaman dan mahluk hidup lain yang telah mengalami proses pembusukan (dekomposisi) oleh mikro organisme pengurai sehingga warna, rupa, tekstur dan kadar airnya tidak serupa dengan bahan aslinya. Sedangkan pupuk anorganik adalah pupuk yang dibuat dari bahan mineral atau senyawa kimia melalui proses industri.

\section{Metode}

Penelitian ini di laksanakan pada bulan 11 Juni sampai Agustus 2016 di kebun percobaan Fakultas Pertanian, Universitas Timor Kelurahan Sasi, kecamatan Kota Kefamenanu, kabupaten TTU. Topografi berbukit-bukit dengan ketinggian $\pm 400 \mathrm{~m}$ di atas permukaan laut, curah hujan 900-1.500 $\mathrm{mm} /$ tahun, suhu udara sekitar $27^{\circ} \mathrm{C}$.

Penelitian ini di lakukan dengan menggunakan Rancangan Acak Lengkap (RAL) faktorial $3 \times 3$ yang diulang 3 kali. Faktor pertama adalah jenis biochar dari 3 aras yakni kontrol $\left(B_{0}\right)$, arang sekam padi $\left(B_{1}\right)$, arang serbuk gergaji $\left(\mathrm{B}_{2}\right)$.. Faktor kedua adalah jenis pupuk yang terdiri dari 3 aras yakni kontrol $\left(\mathrm{P}_{0}\right)$, pupuk kandang sapi $\left(\mathrm{P}_{1}\right)$, pupuk guano $\left(\mathrm{P}_{2}\right), \mathrm{B}_{0} \mathrm{P}_{0}, \mathrm{~B}_{0} \mathrm{P}_{1}, \mathrm{~B}_{0} \mathrm{P}_{2}, \mathrm{~B}_{1} \mathrm{P}_{0}, \mathrm{~B}_{1} \mathrm{P}_{1}$, $\mathrm{B}_{1} \mathrm{P}_{2}, \mathrm{~B}_{2} \mathrm{P}_{0}, \mathrm{~B}_{2} \mathrm{P}_{1}, \mathrm{~B}_{2} \mathrm{P}_{2}$

Sekam padi yang dipakai berasal desa Tainsala, bahan bahan dalam pembuatan biochar yaitu sekam padi sebanyak 10 karung, cerobong dengan panjang $120 \mathrm{~cm}$, dimeter $30 \mathrm{~cm}$. Pembuatan arang sekam dilakukan dengan cara corobong diletakan posisi meninggi dan sekam padi ditabur mengelilingi cerobong sampai puncak tertinggi kemudian dilakukan pembakaran dari bagian atas cerobong, setelah pembakaran sekitar 12 jam sekam padi tersebut berubah wujut menjadi arang dan siram dengan air sampai benar basah, dijemur hingga benar benar kering dan siap untuk di pakai.

Sebuk gergaji yang dipakai berasal dari kelurahan Bansone, bahan bahan dalam pembuatan biochar yaitu sekam padi sebanyak 10 karung, cerobong dengan panjang $120 \mathrm{~cm}$, dimeter $30 \mathrm{~cm}$. Pembuatan arang sekam dilakukan dengan cara corobong diletakan posisi meninggi dan serbuk gergaji ditabur mengelilingi cerobong sampai puncak tertinggi kemudian dilakukan pembakaran dari bagian atas cerobong, setelah pembakaran sekitar 12 jam arang serbuk gergaji tersebut berubah wujut menjadi arang dan siram dengan air sampai keseluruhannya basah, dijemur hingga benar benar kering dan siap untuk di pakai.

Pupuk kandang sapi yang di ambil dari kandang sapi Fakultas Pertanian Universitas Timor yang dikomposkan terlebih dahulu. Pupuk guano berasal dari Desa Mamsena. Kedua pupuk organik dihaluskan menggunakan ayakan dengan dimeter lubang $2 \mathrm{~mm}$ dan siap untuk di pakai.

Pot untuk penelitian ini berupa Ember kapasitas $4 \mathrm{~kg}$, ember diisi dengan media tanam berupa campuran tanah hitam (top soil) kemudian dicampur dengan arang sekam padi dan arang serbuk gergaji dengan takaran yang sama $5 \mathrm{t} / \mathrm{ha}(8,5 \mathrm{~g})$, serta pupuk kandang dan guano masing-masing dengan takaran 5 $\mathrm{t} / \mathrm{ha}(8,3 \mathrm{~g})$ dan $2,5 \mathrm{t} / \mathrm{ha}(0,42 \mathrm{~g})$. Setelah diisi ke dalam pot, media disiram dan dibiarkan selama 2 minggu sebelum ditanam.

Benih yang digunakan adalah benih kacang hijau yang dibeli dari toko sarana produksi pertanian terdekat yang bebas dari organisme pengganggu tanaman. Penyulaman dilakukan sejak tanam sampai tanaman berumur 14 hari setelah tanam. Penyulaman dilakukan terhadap bibit yang tumbuhnya tidak normal atau tidak tumbuh. Dengan menggantikan bibit yang tidak normal atau mati dengan bibit cadangan yang disiapkan. Penyiraman dilakukan pada pagi dan sore hari menggunakan gembor. Penyiangan gulma dilakukan dengan cara mencabut gulma yang tumbuh bersamaan dengan tanaman kacang hijau. Panen dilakukan pada umur kurang lebih 90 hari setelah tanam.

Data hasil pengamatan kemudian dianalisis dengan menggunakan sidik ragam (Anova) Rancangan Acak Kelompok (RAL). Rata-rata perlakuan selanjutnya diuji lanjut dengan menggunakan Duncan Multiple Range Test (DMRT) dengan tingkat signifikasi 5\% sesuai petunjuk Gomez dan Gomez (2010). Analisis data menggunakan program SAS 9.1. 


\section{Hasil dan Pembahasan}

\subsection{Derajat Keasaman (pH)}

Hasil analisis sidik ragam (Anova) menunjukkan bahwa tidak terjadi interaksi antar perlakuan terhadap pengamatan $\mathrm{pH}$. Faktor tunggal perlakuan jenis biochar tidak berbeda nyata antara level perlakuannya, namun yang mendekati $\mathrm{pH}$ netral adalah arang sekam padi. Sedangkan faktor tunggal jenis pupuk organik yang menghasilkan $\mathrm{pH}$ media tumbuh mendekati netral adalah pupuk guano, lebih rendah dari pupuk kandang sapi meskipun tidak berbeda nyata tetapi berbeda nyata dengan control.

\section{Tabel 1. Derajat Keasaman Media $(\mathrm{pH})$}

\begin{tabular}{lcccc}
\hline \multirow{2}{*}{ Jenis Biochar } & Kontrol & $\begin{array}{c}\text { Pupuk Kandang } \\
\text { Sapi }\end{array}$ & $\begin{array}{c}\text { Pupuk } \\
\text { Guano }\end{array}$ & \multirow{2}{*}{ Rerata } \\
\cline { 2 - 5 } & 8.20 & 8.01 & 7.98 & $8.06 \mathrm{a}$ \\
\hline Kontrol & 8.05 & 8.00 & 7.92 & $7.99 \mathrm{a}$ \\
Arang Sekam Padi & 8.19 & 8.04 & 7.97 & $8.07 \mathrm{a}$ \\
Arang Serbuk Gergaji & $8.15 \mathrm{a}$ & $8.02 \mathrm{~b}$ & $7.96 \mathrm{~b}$ & $(-)$ \\
\hline Rerata & \multicolumn{3}{c}{ - } & Angka yang diikuti dengan huruf yang sama pada kolom atau baris yang sama \\
\hline Keterangan: & tidak berbeda nyata menurut uji DMRT @ 5\%, (-): Tidak terjadi interaksi antara \\
& factor.
\end{tabular}

\subsection{Daya Hantar Listrik (DHL)}

Hasil analisis sidik ragam (Anova) menunjukkan bahwa tidak terjadi interaksi antar perlakuan terhadap pengamatan daya hantar listrik. Faktor tunggal jenis biochar yang menghasilkan daya hantar listrik tertinggi adalah arang sekam padi, meskipun tidak berbeda nyata dengan lainnya. Sedangkan faktor tunggal jenis pupuk organik yang menghasilkan daya hantar listrik tertinggi adalah pupuk guano berbeda nyata dengan perlakuan lainnya.

Tabel 2. Daya Hantar Listrik

\begin{tabular}{|c|c|c|c|c|}
\hline \multirow[b]{2}{*}{ Jenis Biochar } & \multicolumn{3}{|c|}{ Jenis Pupuk Organik } & \multirow[b]{2}{*}{ Rerata } \\
\hline & Kontrol & $\begin{array}{c}\text { Pupuk } \\
\text { Kandang Sapi }\end{array}$ & $\begin{array}{l}\text { Pupuk } \\
\text { Guano }\end{array}$ & \\
\hline Kontrol & 599.44 & 758.80 & 1052.20 & $803.48 \mathrm{a}$ \\
\hline Arang sekam padi & 671.66 & 802.80 & 1134.80 & 869.76 a \\
\hline Arang serbuk gergaji & 750,00 & 807.60 & 826.75 & $794.79 \mathrm{a}$ \\
\hline Rerata & $673.70 \mathrm{~b}$ & $789.73 \mathrm{~b}$ & $1004.59 \mathrm{a}$ & $(-)$ \\
\hline Keterangan: & & $\begin{array}{l}\text { ruf yang san } \\
\text { i DMRT @ }\end{array}$ & $\begin{array}{l}\text { kolom ata } \\
\text { Tidak terj }\end{array}$ & $\begin{array}{l}\text { fang sama } \\
\text { ksi antara }\end{array}$ \\
\hline
\end{tabular}

\subsection{Tinggi Tanaman}

Hasil analisis sidik ragam (Anova) menunjukkan bahwa tidak terjadi interaksi antar perlakuan terhadap tinggi tanaman. Faktor tunggal jenis Biochar tidak berbeda nyata dari awal pengamatan sampai akhir pengamatan. Faktor tunggal jenis pupuk organik menunjukkan pada awal pengamatan tidak beda nyata di antara semua level tetapi pada pengamatan 28 HST dan $42 \mathrm{HST}$ menunjukkan bahwa pengaruh perlakuan pupuk guano menghasilkan tanaman tertinggi berbeda nyata dibandingkan perlakuan lainnya.

Tabel 3. Tinggi Tanaman (cm)

\begin{tabular}{cllccc}
$\begin{array}{c}\text { Waktu } \\
\text { Pengamatan }\end{array}$ & Jenis Biochar & \multicolumn{3}{c}{ Jenis Pupuk Organik } & \multirow{2}{*}{ Rerata } \\
\cline { 3 - 5 } & & Kontrol & $\begin{array}{c}\text { Pupuk } \\
\text { Kandang Sapi }\end{array}$ & $\begin{array}{c}\text { Pupuk } \\
\text { Guano }\end{array}$ & \\
\hline \multirow{3}{*}{$14 \mathrm{HST}$} & Kontrol & 11.78 & 11.85 & 12.15 & $11.92 \mathrm{a}$ \\
& Arang Sekam Padi & 11.60 & 11.80 & 11.72 & $11.70 \mathrm{a}$ \\
& Arang Sebuk Gergaji & 11.19 & 10.55 & 10.90 & $10.88 \mathrm{a}$ \\
\cline { 2 - 5 } & Rerata & $11.52 \mathrm{a}$ & $11.40 \mathrm{a}$ & $11.59 \mathrm{a}$ & $(-)$ \\
\hline \multirow{3}{*}{$28 \mathrm{HST}$} & Kontrol & 18.88 & 19.40 & 21.49 & $19.92 \mathrm{a}$ \\
& Arang Sekam Padi & 17.62 & 19.28 & 22.22 & $19.70 \mathrm{a}$ \\
& Arang Sebuk Gergaji & 17.38 & 18.80 & 21.96 & $19.02 \mathrm{a}$ \\
\hline \multirow{3}{*}{$42 \mathrm{HST}$} & Rerata & $17.96 \mathrm{~b}$ & $18.80 \mathrm{~b}$ & $21.89 \mathrm{a}$ & $(-)$ \\
& Kontrol & 28.40 & 29.66 & 31.61 & $29.89 \mathrm{a}$ \\
& Arang Sekam Padi & 28.27 & 29.42 & 33.06 & $30.25 \mathrm{a}$ \\
& Arang Sebuk Gergaji & 28.95 & 29.10 & 32.96 & $30.33 \mathrm{a}$ \\
\hline & Rerata & $28.54 \mathrm{~b}$ & $29.39 \mathrm{~b}$ & $32.54 \mathrm{a}$ & $(-)$ \\
\hline Keterangan: & Angka yang diikuti dengan huruf yang sama pada kolom atau baris yang sama tidak \\
& berbeda nyata menurut uji DMRT @ 5\%, (-): Tidak terjadi interaksi antara factor.
\end{tabular}

\subsection{Jumlah Daun}

Hasil analisis sidik ragam (Anova) menunjukkan bahwa tidak terjadi interaksi antar perlakuan terhadap parameter pengamatan jumlah daun. Faktor tunggal perlakuan jenis Biochar tidak berbeda nyata dari awal pengamatan sampai akhir pengamatan. Faktor tunggal jenis pupuk menunjukkan bahwa awal pengamatan tidak terjadi beda nyata tetapi pada pengamatan 28 HST dan 42 HST menunjukkan bahwa pengaruh tunggal pupuk guano menghasilkan daun tanaman terbanyak berbeda nyata dibandingkan perlakuan lainnya. Sedangkan faktor tunggal jenis Biochar yang menghasilkan daun terbanyak adalah arang sekam padi.

\begin{tabular}{|c|c|c|c|c|c|}
\hline \multirow[b]{2}{*}{$\begin{array}{c}\text { Waktu } \\
\text { Pengamatan }\end{array}$} & \multirow[b]{2}{*}{ Jenis Biochar } & \multicolumn{3}{|c|}{ Jenis Pupuk Organik } & \multirow[t]{2}{*}{ Rerata } \\
\hline & & Kontrol & $\begin{array}{c}\text { Pupuk Kandang } \\
\text { Sapi } \\
\end{array}$ & $\begin{array}{l}\text { Pupuk } \\
\text { Guano }\end{array}$ & \\
\hline \multirow{4}{*}{$14 \mathrm{HST}$} & Kontrol & 2.00 & 2.00 & 2.00 & $2.00 \mathrm{a}$ \\
\hline & Arang Sekam Padi & 2.00 & 2.00 & 2.00 & $2.00 \mathrm{a}$ \\
\hline & Arang Sebuk Gergaji & 2.00 & 2.00 & 2.00 & $2.00 \mathrm{a}$ \\
\hline & Rerata & $2.00 \mathrm{a}$ & $2.00 \mathrm{a}$ & $2.00 \mathrm{a}$ & $(-)$ \\
\hline \multirow{4}{*}{$28 \mathrm{HST}$} & Kontrol & 18.14 & 19.68 & 21.45 & $19.75 \mathrm{a}$ \\
\hline & Arang Sekam Padi & 17.43 & 19.82 & 22.65 & $19.96 \mathrm{a}$ \\
\hline & Arang Sebuk Gergaji & 17.21 & 17.99 & 21.70 & $18.96 \mathrm{a}$ \\
\hline & Rerata & $21.93 \mathrm{a}$ & $19.16 \mathrm{~b}$ & $21.93 \mathrm{a}$ & $(-)$ \\
\hline \multirow{4}{*}{$42 \mathrm{HST}$} & Kontrol & 12.90 & 12.90 & 13.70 & $13.16 \mathrm{a}$ \\
\hline & Arang Sekam Padi & 12.90 & 13.00 & 13.90 & $13.26 \mathrm{a}$ \\
\hline & Arang Sebuk Gergaji & 12.00 & 13.20 & 14.30 & $13.16 \mathrm{a}$ \\
\hline & Rerata & $12.60 \mathrm{~b}$ & $13.03 \mathrm{~b}$ & $13.96 \mathrm{a}$ & $(-)$ \\
\hline
\end{tabular}

\subsection{Diameter Batang $(\mathbf{c m})$}

Hasil analisis sidik ragam (Anova) menunjukkan bahwa tidak terjadi interaksi antar perlakuan pada parameter pengamatan diameter batang. Faktor tunggal perlakuan jenis biochar tidak berbeda nyata dari awal pengamatan sampai akhir pengamatan. Faktor tunggal jenis pupuk menunjukkan bahwa awal pengamatan tidak terjadi beda nyata tetapi pada pengamatan $28 \mathrm{HST}$ dan 42 HST menunjukkan bahwa pengaruh perlakuan pupuk guano menghasilkan diameter tanaman terbesar berbeda nyata dengan perlakuan lainnya. Sedangkan faktor tunggal jenis biochar yang menghasilkan batang terbesar adalah arang sekam padi.

Tabel 5. Diameter Batang (cm)

\begin{tabular}{|c|c|c|c|c|c|}
\hline \multirow[b]{2}{*}{$\begin{array}{c}\text { Waktu } \\
\text { Pengamatan }\end{array}$} & \multirow[b]{2}{*}{ Jenis Biochar } & \multicolumn{3}{|c|}{ Jenis Pupuk Organik } & \multirow[b]{2}{*}{ Rerata } \\
\hline & & Kontrol & $\begin{array}{c}\text { Pupuk Kandang } \\
\text { Sapi }\end{array}$ & $\begin{array}{l}\text { Pupuk } \\
\text { Guano }\end{array}$ & \\
\hline \multirow{4}{*}{$14 \mathrm{HST}$} & Kontrol & 0.10 & 0.11 & 0.11 & $0.10 \mathrm{a}$ \\
\hline & Arang Sekam Padi & 0.11 & 0.10 & 0.10 & $0.11 \mathrm{a}$ \\
\hline & Arang Sebuk Gergaji & 0.12 & 0.10 & 0.11 & $0.11 \mathrm{a}$ \\
\hline & Rerata & $0.11 \mathrm{a}$ & $0.10 \mathrm{a}$ & $0.12 \mathrm{a}$ & $(-)$ \\
\hline \multirow{4}{*}{$28 \mathrm{HST}$} & Kontrol & 0.20 & 0.22 & 0.22 & $0.21 \mathrm{a}$ \\
\hline & Arang Sekam Padi & 0.22 & 0.20 & 0.27 & $0.23 \mathrm{a}$ \\
\hline & Arang Sebuk Gergaji & 0.20 & 0.21 & 0.25 & $0.22 \mathrm{a}$ \\
\hline & Rerata & $0.20 \mathrm{~b}$ & $0.21 \mathrm{~b}$ & $0.24 \mathrm{a}$ & $(-)$ \\
\hline \multirow{4}{*}{$42 \mathrm{HST}$} & Kontrol & 0.30 & 0.32 & 0.32 & $0.31 \mathrm{~b}$ \\
\hline & Arang Sekam Padi & 0.33 & 0.32 & 0.39 & $0.34 \mathrm{a}$ \\
\hline & Arang Sebuk Gergaji & 0.33 & 0.33 & 0.37 & $0.31 \mathrm{~b}$ \\
\hline & Rerata & $0.32 \mathrm{~b}$ & $0.32 \mathrm{~b}$ & $0.36 \mathrm{a}$ & $(-)$ \\
\hline
\end{tabular}

\subsection{Berat Segar Akar}

Hasil analisis sidik ragam (Anova) menunjukkan bahwa tidak terjadi interaksi antar perlakuan pada parameter pengamatan berat segar akar. Faktor tunggal perlakuan jenis biochar maupun jenis pupuk tidak berbeda nyata di antara masing-masing level, namun akar segar terberat diperoleh pada pengaruh faktor tunggal Arang sekam padi dan faktor tunggal pupuk guano.

\section{Tabel 6. Berat Segar Akar (g)}

\begin{tabular}{lcccc}
\hline \multirow{2}{*}{ Jenis Biochar } & \multirow{3}{c}{ Jenis Pupuk Organik } & \multirow{2}{*}{ Rerata } \\
\cline { 2 - 4 } & Kontrol & $\begin{array}{c}\text { Pupuk Kandang } \\
\text { Sapi }\end{array}$ & $\begin{array}{c}\text { Pupuk } \\
\text { Guano }\end{array}$ & \\
\hline Kontrol & 4.92 & 6.12 & 5.37 & $5.47 \mathrm{a}$ \\
Arang Sekam Padi & 5.20 & 7.75 & 8.74 & $7.23 \mathrm{a}$ \\
Arang Serbuk Gergaji & 6.28 & 6.17 & 7.09 & $6.51 \mathrm{a}$ \\
\hline \multicolumn{1}{c}{ Rerata } & $5.47 \mathrm{a}$ & $6.68 \mathrm{a}$ & $7.06 \mathrm{a}$ & $(-)$ \\
\hline
\end{tabular}

Keterangan: Angka yang diikuti dengan huruf yang sama pada kolom atau baris yang sama tidak berbeda nyata menurut uji DMRT @ 5\%, (-): Tidak terjadi interaksi antara factor.

\subsection{Berat Kering Akar}

Hasil analisis sidik ragam (Anova) menunjukkan bahwa tidak terjadi interaksi antara perlakuan jenis biochar dan jenis pupuk organik terhadap berat kering akar. Faktor tunggal perlakuan jenis biochar maupun jenis pupuk tidak berbeda nyata di antara masing-masing level, namun akar kering terberat diperoleh pada pengaruh faktor tunggal Arang sekam padi dan faktor tunggal pupuk guano.

\section{Tabel 7. Berat Kering Akar (g)}

\begin{tabular}{lcccc}
\hline \multirow{2}{*}{ Jenis Biochar } & Kontrol & $\begin{array}{c}\text { Pupuk Kandang } \\
\text { Sapi }\end{array}$ & $\begin{array}{c}\text { Pupuk } \\
\text { Guano }\end{array}$ & \multirow{2}{*}{ Rerata } \\
\cline { 2 - 4 } & 0.50 & 0.72 & 0.76 & $0.66 \mathrm{a}$ \\
Kontrol & 0.60 & 1.04 & 0.99 & $0.88 \mathrm{a}$ \\
Arang Sekam Padi & 0.40 & 0.34 & 0.65 & $0.46 \mathrm{ab}$ \\
Arang Serbuk Gergaji & $0.50 \mathrm{a}$ & $0.70 \mathrm{a}$ & $0.80 \mathrm{a}$ & $(-)$ \\
\hline \multicolumn{2}{c}{ Rerata } & Angka yang diikuti dengan huruf yang sama pada kolom atau baris yang sama tidak \\
\hline Keterangan: & berbeda nyata menurut uji DMRT @ 5\%, (-): Tidak terjadi interaksi antara factor.
\end{tabular}




\subsection{Berat Segar Batang}

Hasil analisis sidik ragam (Anova) menunjukkan bahwa tidak terjadi interaksi antar perlakuan terhadap berat segar batang. Faktor tunggal perlakuan jenis biochar maupun jenis pupuk organik tidak berbeda nyata, namun batang segar tanaman terberat diberikan oleh pengaruh tunggal pupuk kandang sapi dan arang serbuk gergaji.

\section{Tabel 8. Berat Segar Batang (g)}

\begin{tabular}{lcccc}
\hline \multirow{2}{*}{ Jenis Biochar } & \multicolumn{3}{c}{ Jenis Pupuk Organik } & \multirow{2}{*}{ Rerata } \\
\cline { 2 - 4 } & Kontrol & $\begin{array}{c}\text { Pupuk Kandang } \\
\text { Sapi }\end{array}$ & $\begin{array}{c}\text { Pupuk } \\
\text { Guano }\end{array}$ & \\
\hline Kontrol & 4.42 & 4.34 & 3.98 & $4.24 \mathrm{a}$ \\
Arang Sekam Padi & 3.63 & 5.27 & 4.86 & $4.59 \mathrm{a}$ \\
Arang Serbuk Gergaji & 4.24 & 5.88 & 4.38 & $4.83 \mathrm{a}$ \\
\hline \multicolumn{1}{c}{ Rerata } & $4.10 \mathrm{a}$ & $5.16 \mathrm{a}$ & $4.41 \mathrm{a}$ & $(-)$ \\
\hline Keterangan: & Angka yang diikuti dengan huruf yang sama pada kolom atau baris yang sama tidak berbeda \\
& nyata menurut uji DMRT @ 5\%, (-): Tidak terjadi interaksi antara factor.
\end{tabular}

\subsection{Berat Kering Batang}

Hasil analisis sidik ragam (Anova) menunjukkan bahwa antara perlakuan jenis biochar dan jenis pupuk organik tidak tejadi interaksi pada pengamatan berat kering batang. Faktor tunggal perlakuan jenis biochar maupun jenis pupuk organik tidak berbeda nyata antara semua levelnya, namun batang kering tanaman terberat diberikan oleh pengaruh tunggal pupuk kandang sapi dan arang serbuk gergaji.

\section{Tabel 9. Berat Kering Batang (g)}

\begin{tabular}{lcccc}
\hline \multirow{2}{*}{ Jenis Biochar } & Kontrol & $\begin{array}{c}\text { Pupuk Kandang } \\
\text { Sapi }\end{array}$ & $\begin{array}{c}\text { Pupuk } \\
\text { Guano }\end{array}$ & \multirow{2}{*}{ Rerata } \\
\cline { 2 - 4 } & 0.85 & 0.65 & 0.70 & $0.73 \mathrm{a}$ \\
\hline Kontrol & 0.59 & 1.04 & 0.73 & $0.78 \mathrm{a}$ \\
Arang Sekam Padi & 0.78 & 0.97 & 0.88 & $0.87 \mathrm{a}$ \\
Arang Serbuk Gergaji & 0.74 a & 0.88 a & 0.77 a & $(-)$ \\
\hline \multicolumn{2}{c}{ Rerata } & Angka yang diikuti dengan huruf yang sama pada kolom atau baris yang sama tidak \\
\hline Keterangan: & berbeda nyata menurut uji DMRT @ 5\%, (-): Tidak terjadi interaksi antara factor.
\end{tabular}

\subsection{Berat Segar Daun}

Hasil analisis sidik ragam (Anova) menunjukkan bahwa tidak terjadi interaksi antar perlakuan jenis biochar dan jenis pupuk organik terhadap parameter pengamatan berat segar daun. Faktor tunggal perlakuan jenis biochar maupun jenis pupuk organik tidak berbeda nyata antar levelnya, namun daun segar terberat diperoleh dari pengaruh tunggal masing-masing faktor, yakni pupuk guano dan arang sekam padi.

$\underline{\text { Tabel 10. Berat Segar Daun (g) }}$

\begin{tabular}{|c|c|c|c|c|}
\hline \multirow[b]{2}{*}{ Jenis Biochar } & \multicolumn{3}{|c|}{ Jenis Pupuk Organik } & \multirow[b]{2}{*}{ Rerata } \\
\hline & Kontrol & $\begin{array}{l}\text { Pupuk Kandang } \\
\text { Sapi }\end{array}$ & $\begin{array}{l}\text { Pupuk } \\
\text { Guano }\end{array}$ & \\
\hline Kontrol & 4.16 & 5.09 & 7.35 & $5.53 \mathrm{a}$ \\
\hline Arang Sekam Padi & 4.40 & 5.66 & 7.86 & $5.97 \mathrm{a}$ \\
\hline Arangserbuk Gergaji & 5.04 & 5.84 & 6.42 & $5.77 \mathrm{a}$ \\
\hline Rerata & $4.53 \mathrm{ab}$ & $5.53 \mathrm{a}$ & $7.21 \mathrm{a}$ & $(-)$ \\
\hline
\end{tabular}

\subsection{Berat Kering Daun}

Hasil analisis sidik ragam (Anova) menunjukkan bahwa tidak terjadi interaksi antar perlakuan jenis biochar dan jenis pupuk organik terhadap parameter berat kering daun. perlakuan jenis biochar dan jenis pupuk organik tidak terjadi beda nyata antar levelnya, namun pengaruh masing-masing faktor tunggal, yakni pupuk guano dan tanpa biochar (kontrol) menghasilkan daun kering terberat dibandingkan pelakuan lainnya.

Tabel 11. Berat Kering Daun (g)

\begin{tabular}{|c|c|c|c|c|}
\hline \multirow[b]{2}{*}{ Jenis Biochar } & \multicolumn{3}{|c|}{ Jenis Pupuk Organik } & \multirow[b]{2}{*}{ Rerata } \\
\hline & Kontrol & $\begin{array}{c}\text { Pupuk Kandang } \\
\text { Sapi }\end{array}$ & $\begin{array}{l}\text { Pupuk } \\
\text { Guano }\end{array}$ & \\
\hline Kontrol & 1.06 & 1.27 & 1.84 & $1.39 \mathrm{a}$ \\
\hline Arang Sekam Padi & 1.03 & 0.83 & 1.74 & $1.20 \mathrm{a}$ \\
\hline Arangserbuk Gergaji & 1.41 & 1.39 & 0.84 & $1.21 \mathrm{a}$ \\
\hline Rerata & $1.17 \mathrm{a}$ & $1.16 \mathrm{a}$ & $1.47 \mathrm{a}$ & $(-)$ \\
\hline
\end{tabular}

\subsection{Total Bintil Akar}

Hasil analisis sidik ragam (Anova) menunjukkan bahwa tidak terjadi interaksi antar perlakuan jenis biochar dan jenis pupuk organik namun total bintil akar terbanyak diperoleh dari perlakuan masing-masing faktor tunggal pupuk guano dan arang sekam padi, meskipun tidak berbeda nyata dengan level perlakuan lainya.

\section{Tabel 12. Total Bintil Akar}

\begin{tabular}{lcccc}
\hline \multirow{2}{*}{ Jenis Biochar } & \multicolumn{3}{c}{ Jenis Pupuk Organik } & \multirow{2}{*}{ Rerata } \\
\cline { 2 - 4 } & \multirow{2}{*}{ Kontrol } & $\begin{array}{c}\text { Pupuk Kandang } \\
\text { Sapi }\end{array}$ & $\begin{array}{r}\text { Pupuk } \\
\text { Guano }\end{array}$ \\
\hline Kontrol & 81.00 & 65.50 & 83.50 & $76.67 \mathrm{a}$ \\
Arang Sekam Padi & 85.75 & 50.00 & 130.25 & $88.67 \mathrm{a}$ \\
Arang Serbuk Gergaji & 41.50 & 66.25 & 66.25 & $58.00 \mathrm{a}$ \\
\hline \multicolumn{1}{c}{ Rerata } & $69.42 \mathrm{a}$ & $60.58 \mathrm{a}$ & $93.33 \mathrm{a}$ & $(-)$ \\
\hline Keterangan: $\quad$ Angka yang diikuti dengan huruf yang sama pada kolom atau baris yang sama tidak
\end{tabular}

Angka yang diikuti dengan huruf yang sama pada kolom atau baris yang sama ti
berbeda nyata menurut uji DMRT @ $5 \%,(-)$ : Tidak terjadi interaksi antara faktor

\subsection{Bintil Akar Besar}

Hasil analisis sidik ragam (Anova) menunjukkan bahwa tidak terjadi interaksi antar perlakuan jenis biochar dan jenis pupuk organik tidak berbeda nyata namun bintil akar pada perlakuan tanpa biochar (kontrol) cenderung lebih banyak dibandingkan dengan tanaman yang lainnya. Sedangkan faktor tunggal jenis pupuk organik yang menghasilkan bintil akar terbeanyak diperoleh pada perlakuan pupuk kandang sapi.

$\underline{\text { Tabel 13. Bintil Akar Besar }}$

\begin{tabular}{lcccc}
\hline \multirow{2}{*}{ Jenis Biochar } & Kontrol & $\begin{array}{c}\text { Pupuk Kandang } \\
\text { Sapi }\end{array}$ & $\begin{array}{c}\text { Pupuk } \\
\text { Guano }\end{array}$ & Rerata \\
\cline { 2 - 4 } & 16.50 & 24.50 & 18.50 & $19.83 \mathrm{a}$ \\
\hline Kontrol & 19.25 & 15.75 & 18.75 & $17.91 \mathrm{a}$ \\
Arang Sekam Padi & 16.00 & 18.00 & 20.25 & $18.08 \mathrm{a}$ \\
Arang Serbuk Gergaji & 17.25 a & $19.41 \mathrm{a}$ & $19.16 \mathrm{a}$ & $(-)$ \\
\hline \multicolumn{2}{c}{ Rerata } & Angka yang diikuti dengan huruf yang sama pada kolom atau baris yang sama tidak \\
\hline Keterangan: & berbeda nyata menurut uji DMRT @ 5\%, (-): Tidak terjadi interaksi antara factor.
\end{tabular}

\subsection{Bintil Akar Kecil}

Hasil sidik ragam (anova) menunjukan tidak terjadi interaksi antara perlakuan jenis biochar dan jenis pupuk organik terhadap parameter jumlah bintil akar kecil. Pengaruh faktor tunggal pupuk guano dan faktor tunggal arang sekam yang menghasilkan bintil akar kecil terbanyak diikuti degan perlakuan lainnya.

Tabel 14. Bintil Akar Besar

\begin{tabular}{|c|c|c|c|c|}
\hline \multirow[b]{2}{*}{ Jenis Biochar } & \multicolumn{3}{|c|}{ Jenis Pupuk Organik } & \multirow[b]{2}{*}{ Rerata } \\
\hline & Kontrol & $\begin{array}{c}\text { Pupuk Kandang } \\
\text { Sapi }\end{array}$ & $\begin{array}{l}\text { Pupuk } \\
\text { Guano }\end{array}$ & \\
\hline Kontrol & 66.50 & 41.00 & 65.00 & $57.50 \mathrm{a}$ \\
\hline Arang Sekam Padi & 66.50 & 34.25 & 111.75 & $70.83 \mathrm{a}$ \\
\hline Arang Serbuk Gergaji & 25.50 & 48.25 & 46.00 & $39.92 \mathrm{a}$ \\
\hline Rerata & $52.83 \mathrm{a}$ & $41.17 \mathrm{a}$ & $74.25 \mathrm{a}$ & $(-)$ \\
\hline
\end{tabular}

\subsection{Bintil Akar Efektif}

Hasil analisis sidik ragam (Anova) menunjukkan bahwa tidak terjadi interaksi antar perlakuan pada pengamatan bintil akar efektif. Antara level perlakuan baik jenis biohar maupun jenis pupuk organik tidak berbeda nyata namun faktor tunggal arang sekam padi dan faktor tunggal pupuk guano menghasilkan bintil akar efektif terbanyak.

\section{Tabel 15. Bintil Akar Efektif}

\begin{tabular}{|c|c|c|c|c|}
\hline \multirow[b]{2}{*}{ Jenis Biochar } & \multicolumn{3}{|c|}{ Jenis Pupuk Organik } & \multirow[b]{2}{*}{ Rerata } \\
\hline & Kontrol & $\begin{array}{c}\text { Pupuk Kandang } \\
\text { Sapi }\end{array}$ & $\begin{array}{l}\text { Pupuk } \\
\text { Guano }\end{array}$ & \\
\hline Kontrol & 34.25 & 40.50 & 58.25 & $44.33 \mathrm{a}$ \\
\hline Arang Sekam Padi & 80.25 & 45.75 & 55.50 & $60.50 \mathrm{a}$ \\
\hline Arang Serbuk Gergaji & 20.75 & 61.00 & 58.50 & $46.75 \mathrm{a}$ \\
\hline Rerata & $45.08 \mathrm{a}$ & $49.08 \mathrm{a}$ & $57.42 \mathrm{a}$ & $(-)$ \\
\hline
\end{tabular}

\subsection{Bintil Akar Tidak Efektif}

Hasil sidik ragam (anova) menunjukan dari kedua faktor perlakuan jenis biochar dan jenis pupuk organik tidak terjadi interaksi dan tidak berbeda nyata antar level perlakuannya, namun jenis biochar yaitu arang sekam padi kurang menghasilkan bintil akar tidak efektif dari pada arang serbuk gergaji, walaupun masih lebih banyak dibanding kontrol. Sedangkan faktor tunggal pupuk organik yang kurang menghasilkan bintil akar tidak efektif adalah pupuk guano dibandingkan pupuk kandang sapi, meskipun masih lebih banyak dari control.

Tabel 16. Bintil Akar Tidak Efektif

\begin{tabular}{|c|c|c|c|c|}
\hline \multirow[b]{2}{*}{ Jenis Biochar } & \multicolumn{3}{|c|}{ Jenis Pupuk Organik } & \multirow[b]{2}{*}{ Rerata } \\
\hline & Kontrol & $\begin{array}{c}\text { Pupuk Kandang } \\
\text { Sapi }\end{array}$ & $\begin{array}{l}\text { Pupuk } \\
\text { Guano }\end{array}$ & \\
\hline Kontrol & 2.50 & 4.75 & 1.50 & $2.91 \mathrm{a}$ \\
\hline Arang Sekam Padi & 5.50 & 4.25 & 1.50 & $3.75 \mathrm{a}$ \\
\hline Arang Serbuk Gergaji & 1.50 & 5.25 & 7.75 & $4.83 \mathrm{a}$ \\
\hline Rerata & $3.16 \mathrm{a}$ & $4.75 \mathrm{a}$ & $3.58 \mathrm{a}$ & $(-)$ \\
\hline
\end{tabular}




\subsection{Berat Segar Berangkasan}

Hasil penelitian dan sidik ragam (anova) menunjukan tidak terjadi interaksi antara perlakuan jenis biochar dan jenis pupuk organik. Pengaruh tunggal jenis arang sekam yang menghasilkan brangkasan segar tertinggi pada kontrol tetapi tidak berbeda nyata dengan brangkasan segar dari perlakuan arang serbuk gergaji yang masih lebih berat dibandingkan arang sekam padi. Faktor tunggal pupuk kandang sapi memberikan hasil brangkasan segar paling berat dibandingkan lainnya, sekali pun tidak berbeda nyata.

\section{Tabel 17. Berat Segar Berangkasan (g)}

\begin{tabular}{lcccc}
\hline \multirow{2}{*}{ Jenis Biochar } & Kontrol & $\begin{array}{c}\text { Pupuk Kandang } \\
\text { Sapi }\end{array}$ & $\begin{array}{c}\text { Pupuk } \\
\text { Guano }\end{array}$ & \multirow{2}{*}{ Rerata } \\
\cline { 2 - 4 } & 4.96 & 7.86 & 4.75 & $5.86 \mathrm{a}$ \\
Kontrol & 6.21 & 5.28 & 5.26 & $5.58 \mathrm{a}$ \\
Arang Sekam Padi & 6.01 & 6.64 & 4.73 & $5.79 \mathrm{a}$ \\
Arang Serbuk Gergaji & $5.72 \mathrm{a}$ & $6.59 \mathrm{a}$ & $4.91 \mathrm{a}$ & $(-)$ \\
\hline \multicolumn{2}{c}{ Rerata } & Angka yang diikuti dengan huruf yang sama pada kolom atau baris yang sama tidak
\end{tabular}
berbeda nyata menurut uji DMRT @ 5\%, (-): Tidak terjadi interaksi antara factor.

\subsection{Berat Kering Berangkasan}

Hasil sidik ragam (anova) menunjukan tidak terjadi interaksi antar perlakuan jenis biochar dan jenis pupuk organik. Pengaruh tunggal jenis biochar yang memberikan hasil terberat pada brangkasan kering adalah pada kontrol tetapi tidak berbeda nyata dengan arang sekam padi yang juga memberikan brangkasan kering lebih berat dari pada perlakuan arang serbuk gergaji. Pengaruh tunggal jenis pupuk organik yang memberikan hasil terberat pada brangkasan kering adalah pupuk guano meskipun tidak berbeda nyata dengan perlakuan lainnya.

Tabel 18. Berat Kering Berangkasan (g)

\begin{tabular}{lcccc}
\hline \multirow{2}{*}{ Jenis Biochar } & \multirow{3}{c}{ Jenis Pupuk Organik } & \multirow{2}{*}{ Rerata } \\
\cline { 2 - 4 } & 2.20 & $\begin{array}{c}\text { Pupuk Kandang } \\
\text { Sapi }\end{array}$ & $\begin{array}{c}\text { Pupuk } \\
\text { Guano }\end{array}$ & \\
\hline Kontrol & 1.97 & 2.22 & 2.55 & $2.32 \mathrm{a}$ \\
Arang Sekam Padi & 1.73 & 1.70 & 1.93 & $1.87 \mathrm{a}$ \\
Arang Serbuk Gergaji & $1.97 \mathrm{a}$ & $1.83 \mathrm{a}$ & 2.04 & $1.78 \mathrm{a}$ \\
\hline \multicolumn{2}{c}{ Rerata } & Angka yang diikuti dengan huruf yang sama pada kolom atau baris yang sama tidak
\end{tabular}
berbeda nyata menurut uji DMRT @ 5\%, (-): Tidak terjadi interaksi antara factor.

\subsection{Jumlah Polong Per Tanaman}

Hasil sidik ragam(Anova) menunjukan tidak terjadi interaki anta perlakuan pada pengamatan jumlah polong. Faktor tunggal perlakuan jenis biochar tidak berbeda nyata antara level perlakuannya, namun jumlah polong terbanyak dihasilkan oleh arang sekam padi. Sedangkan faktor tunggal jenis pupuk organik yang menghasilkan polong terbanyak adalah pupuk guano, meskipun tidak berbeda nyata dengan pupuk kandang sapi tetapi berbeda nyata dengan control.

Tabel 19. Jumlah Polong Pertanaman

\begin{tabular}{lcccc}
\hline \multirow{2}{*}{ Jenis Biochar } & Kontrol & $\begin{array}{c}\text { Pupuk Kandang } \\
\text { Sapi }\end{array}$ & $\begin{array}{c}\text { Pupuk } \\
\text { Guano }\end{array}$ & Rerata \\
\cline { 2 - 4 } & 2.41 & 2.83 & 3.25 & $2.83 \mathrm{a}$ \\
\hline Kontrol & 2.83 & 3.00 & 3.58 & $3.13 \mathrm{a}$ \\
Arang Sekam Padi & 2.58 & 2.83 & 3.50 & $2.97 \mathrm{a}$ \\
Arang Serbuk Gergaji & $2.61 \mathrm{~b}$ & $2.88 \mathrm{ab}$ & $3.44 \mathrm{a}$ & $(-)$ \\
\hline \multicolumn{2}{c}{ Rerata } & Angka yang diikuti dengan huruf yang sama pada kolom atau baris yang sama tidak & \\
\hline Keterangan: & berbeda nyata menurut uji DMRT @ 5\%, (-): Tidak terjadi interaksi antara factor.
\end{tabular}

\subsection{Panjang Polong}

Hasil sidik ragam (Anova) menunjukan tidak terjadi interaksi antar faktor perlakuan pemberian biochar dan jenis pupuk organik.

Tabel 20. Panjang Polong (cm)

\begin{tabular}{lcccc}
\hline \multirow{2}{*}{ Jenis Biochar } & \multicolumn{3}{c}{ Jenis Pupuk Organik } & \\
\cline { 2 - 4 } & \multirow{2}{*}{ Kontrol } & $\begin{array}{c}\text { Pupuk Kandang } \\
\text { Sapi }\end{array}$ & $\begin{array}{c}\text { Pupuk } \\
\text { Guano }\end{array}$ & Rerata \\
\hline Kontrol & 7.92 & 8.09 & 8.45 & $8.15 \mathrm{a}$ \\
Arang Sekam Padi & 7.98 & 7.91 & 8.20 & $8.03 \mathrm{a}$ \\
Arang Serbuk Gergaji & 8.42 & 8.42 & 7.97 & $8.27 \mathrm{a}$ \\
\hline \multicolumn{1}{c}{ Rerata } & $8.11 \mathrm{~b}$ & $8.14 \mathrm{ab}$ & $8.20 \mathrm{a}$ & $(-)$ \\
\hline
\end{tabular}

Keterangan: Angka yang diikuti dengan huruf yang sama pada kolom atau baris yang sama tidak berbeda nyata menurut uji DMRT @ 5\%, (-): Tidak terjadi interaksi antara factor.

Faktor tunggal perlakuan jenis biochar tidak berbeda nyata antara level perlakuannya, namun polong terpanjang dihasilkan oleh arang serbuk gergaji. Sedangkan faktor tunggal jenis pupuk organik yang menghasilkan polong terpanjang adalah pupuk guano, meskipun tidak berbeda nyata dengan pupuk kandang sapi tetapi berbeda nyata dengan kontrol.

\subsection{Jumlah Biji Per Polong}

Hasil analisis sidik ragam (Anova) menunjukkan pada pengamatan jumlah biji per polong tidak terjadi interaksi antara jenis biochar dan jenis pupuk organik. Namun penggunaan pupuk guano menghasilkan jumlah biji per polong yang lebih banyak dibandikan perlakuan lainya tetapi tidak berbeda nyata Demikian pula pada level perlakuan jenis biochar tidak berbeda nyata namun jumlah biji per polong terbanyak diperoleh dari perlakuan arang serbuk gergaji.

\section{Tabel 21. Jumlah Biji Per Polong}

\begin{tabular}{lcccc}
\hline \multirow{2}{*}{ Jenis Biochar } & Kontrol & $\begin{array}{c}\text { Pupuk Kandang } \\
\text { Sapi }\end{array}$ & $\begin{array}{c}\text { Pupuk } \\
\text { Guano }\end{array}$ & Rerata \\
\cline { 2 - 5 } & 7.10 & 7.00 & 8.03 & $7.38 \mathrm{a}$ \\
\hline Kontrol & 6.92 & 6.56 & 7.37 & $6.95 \mathrm{a}$ \\
Arang Sekam Padi & 7.36 & 7.29 & 7.28 & $7.31 \mathrm{a}$ \\
Arang Serbuk Gergaji & $7.12 \mathrm{a}$ & $6.95 \mathrm{a}$ & $7.56 \mathrm{a}$ & $(-)$ \\
\hline \multicolumn{2}{c}{ Rerata } & Angka yang diikuti dengan huruf yang sama pada kolom atau baris yang sama tidak \\
\hline Keterangan: & berbeda nyata menurut uji DMRT @ 5\%, (-): Tidak terjadi interaksi antara factor.
\end{tabular}

\subsection{Berat Biji Per Polong}

Analisis sidik ragam (Anova) menunjukan tidak terjadi interaksi di antara perlakuan jenis biochar dan jenis pupuk organik. Perlakuan jenis biochar yang memberikan biji per polong cukup berat yaitu arang serbuk gergaji lebih berat dari pengaruh perlakuan arang sekam padi walaupun masih lebih rendah dar tanpa biochar (kontrol) tetapi tidak berbeda nyata. Sedangkan jenis pupuk organik yang memberikan hasil biji per polong terberat adalah pupuk guano, meskipun tidak berbeda nyata dengan level perlakuan lainnya.

$\underline{\text { Tabel 22. Berat Biji Per Polong (g) }}$

\begin{tabular}{lcccc}
\hline \multirow{2}{*}{ Jenis Biochar } & Kontrol & $\begin{array}{c}\text { Pupuk Kandang } \\
\text { Sapi }\end{array}$ & $\begin{array}{c}\text { Pupuk } \\
\text { Guano }\end{array}$ & \multirow{2}{*}{ Rerata } \\
\cline { 2 - 4 } & 1.07 & 0.81 & 1.02 & $0.97 \mathrm{a}$ \\
Kontrol & 0.78 & 0.83 & 0.84 & $0.82 \mathrm{a}$ \\
Arang Sekam Padi & 0.92 & 0.78 & 0.98 & $0.89 \mathrm{a}$ \\
Arang Serbuk Gergaji & $0.92 \mathrm{a}$ & $0.81 \mathrm{a}$ & $0.95 \mathrm{a}$ & $(-)$ \\
\hline \multicolumn{2}{c}{ Rerata } & Angka yang diikuti dengan huruf yang sama pada kolom atau baris yang sama tidak
\end{tabular}
berbeda nyata menurut uji DMRT @ 5\%, (-): Tidak terjadi interaksi antara factor-

\subsection{Berat 100 Biji}

Hasil sidik ragam (anova) menunjukan bahwa tidak terjadi interaksi antara jenis biochar dan jenis pupuk organik terhadap berat 100 biji. Pada masing masing level pun tidak berbeda nyata. Pengaruh faktor tunggal biochar yang menghasilkan tanaman dengan 100 biji terberat adalah arang serbuk gergaji walaupun tidak berbeda nyata dengan jenis biochar lainnya. Pengaruh tunggal pupuk guano juga menghasilkan 100 biji lebih berat dari pada pengaruh perlakuan pupuk kandang sapi tetapi tidak berbeda nyata dan lebih rendah dari control.

\begin{tabular}{|c|c|c|c|c|}
\hline \multirow[b]{2}{*}{ Jenis Biochar } & \multicolumn{3}{|c|}{ Jenis Pupuk Organik } & \multirow[b]{2}{*}{ Rerata } \\
\hline & Kontrol & $\begin{array}{c}\text { Pupuk Kandang } \\
\text { Sapi } \\
\end{array}$ & $\begin{array}{l}\text { Pupuk } \\
\text { Guano } \\
\end{array}$ & \\
\hline Kontrol & 5.74 & 5.62 & 5.69 & $5.68 \mathrm{a}$ \\
\hline Arang Sekam Padi & 5.74 & 5.72 & 5.48 & $5.64 \mathrm{a}$ \\
\hline Arang Serbuk Gergaji & 5.97 & 5.44 & 6.05 & $5.82 \mathrm{a}$ \\
\hline Rerata & $5.82 \mathrm{a}$ & $5.59 \mathrm{a}$ & $5.74 \mathrm{a}$ & $(-)$ \\
\hline
\end{tabular}

Keterangan: $\quad$ Angka yang diikuti dengan huruf yang sama pada kolom atau baris yang sama tidak berbeda nyata menurut uji DMRT @ 5\%,(-): Tidak terjadi interaksi antara factor.

\subsection{Berat Biji Per Tanaman}

Hasil analisis sidik ragam (Anova) menunjukkan bahwa tidak terjadi interaksi antar faktor jenis biochar dengan jenis pupuk organik. Penggunaan jenis pupuk guano menghasilkan biji per tanaman paling berat dan berbeda nyata dengan jenis pupuk organik lainnya. Jenis biochar yang memberikan biji terberat adalah arang serbuk gergaji meskipun tidak berbeda nyata dengan perlakuan lainnya.

Tabel 24. Berat Biji Per Tanaman (g)

\begin{tabular}{lcccc}
\hline \multirow{2}{*}{ Jenis Biochar } & Kontrol & $\begin{array}{c}\text { Pupuk Kandang } \\
\text { Sapi }\end{array}$ & $\begin{array}{c}\text { Pupuk } \\
\text { Guano }\end{array}$ & Rerata \\
\cline { 2 - 5 } & 2.32 & 2.21 & 3.08 & $2.53 \mathrm{a}$ \\
\hline Kontrol & 2.21 & 2.38 & 3.01 & $2.53 \mathrm{a}$ \\
Arang Sekam Padi & 2.34 & 2.19 & 3.26 & $2.60 \mathrm{a}$ \\
Arang Serbuk Gergaji & $2.29 \mathrm{~b}$ & $2.26 \mathrm{~b}$ & 3.12 a & $(-)$ \\
\hline \multicolumn{2}{c}{ Rerata } & Angka yang diikuti dengan huruf yang sama pada kolom atau baris yang sama tidak \\
\hline Keterangan: & berbeda nyata menurut uji DMRT @ 5\%, (-): Tidak terjadi interaksi antara factor.
\end{tabular}

\subsection{Jumlah Biji Per Tanaman}

Hasil analisis sidik ragam (Anova) menunjukkan bahwa tidak terjadi interaksi antara perlakuan jenis biochar dan jenis pupuk organik terhadap indeks panen. Jenis biochar yang menghasilkan nilai indeks panen tertinggi adalah arang serbuk gergaji walaupun tidak berbeda nyata dengan perlakuan 
lainnya. Sedangkan jenis pupuk organik yang memberikan nilai indeks panen paling tinggi adalah pupuk guano walaupun tidak berbeda nyata dibandingkan degan perlakuan lainya.

Tabel 25. Jumlah Biji Per Tanaman

\begin{tabular}{lcccc}
\hline \multirow{2}{*}{ Jenis Biochar } & Kontrol & $\begin{array}{c}\text { Pupuk Kandang } \\
\text { Sapi }\end{array}$ & $\begin{array}{c}\text { Pupuk } \\
\text { Guano }\end{array}$ & \multirow{2}{*}{ Rerata } \\
\cline { 2 - 4 } & 2.32 & 2.21 & 3.08 & $2.53 \mathrm{a}$ \\
Kontrol & 2.21 & 2.38 & 3.01 & $2.53 \mathrm{a}$ \\
Arang Sekam Padi & 2.34 & 2.19 & 3.26 & $2.60 \mathrm{a}$ \\
Arang Serbuk Gergaji & $2.29 \mathrm{~b}$ & $2.26 \mathrm{~b}$ & $3.12 \mathrm{a}$ & $(-)$ \\
\hline \multicolumn{2}{c}{ Rerata } & Angka yang diikuti dengan huruf yang sama pada kolom atau baris yang sama tidak \\
\hline Keterangan: & berbeda nyata menurut uji DMRT @ 5\%, (-): Tidak terjadi interaksi antara factor.
\end{tabular}

\subsection{Indeks Panen}

Hasil analisis sidik ragam (Anova) menunjukkan bahwa tidak terjadi interaksi antara perlakuan jenis biochar dan jenis pupuk organik terhadap indeks panen. Jenis biochar yang menghasilkan nilai indeks panen tertinggi adalah arang serbuk gergaji walaupun tidak berbeda nyata dengan perlakuan lainnya. Sedangkan jenis pupuk organik yang memberikan nilai indeks panen paling tinggi adalah pupuk guano walaupun tidak berbeda nyata dibandingkan degan perlakuan lainya.

Tabel 26. Indeks Panen

\begin{tabular}{llccc}
\hline \multirow{2}{*}{ Jenis Biochar } & \multicolumn{3}{c}{ Jenis Pupuk Organik } & \multirow{2}{*}{ Rerata } \\
\cline { 2 - 4 } & Kontrol & $\begin{array}{c}\text { Pupuk Kandang } \\
\text { Sapi }\end{array}$ & $\begin{array}{c}\text { Pupuk } \\
\text { Guano }\end{array}$ & \\
\hline Kontrol & 42.73 & 38.81 & 44.58 & $42.04 \mathrm{a}$ \\
Arang Sekam Padi & 42.55 & 44.63 & 46.88 & $44.69 \mathrm{a}$ \\
Arang Serbuk Gergaji & 43.32 & 44.58 & 49.89 & $45.93 \mathrm{a}$ \\
\hline \multicolumn{1}{c}{ Rerata } & 42.87 a & 42.67 a & 47.12 a & $(-)$ \\
\hline Keterangan : Angka yang diikuti dengan huruf yang sama pada kolom atau baris yang sama tidak & berbeda nyata menurut uji DMRT @ 5\%, (-): Tidak terjadi interaksi antara factor.
\end{tabular}

\subsection{Pembahasan}

Penelitian lapangan dengan dua fakror perlakuan yakni jenis biochar dan jenis pupuk kompos telah diamati pengaruhnya terhadap beberapa parameter pertumbuhan dan hasil kacang hijau namun tidak terjadi interaksi antara kedua perlakuan tersebut.

Pengaruh faktor tunggal jenis biochar yang berpengaruh paling optimal terhadap pertumbuhan tanaman kacang hijau adalah arang serbuk gergaji, walaupun dari sebagian besar parameter pertumbuhan pengaruhnya kurang kecuali tinggi tanaman pada $42 \mathrm{HST}$, berat segar dan berat kering batang. Hal ini menunjukkan bahwa penggunaan arang serbuk gergaji dapat mengikat dan menyimpan unsur hara secara lebih baik pada masa pertumbuhan kacang hijau untuk kemudian digunakan pada fase generatifnya. Dengan demikian hasil yang diperoleh, yang ditunjukkan dengan data panjang polong, jumlah biji per polong, berat biji per tanaman, berat biji per polong, berat 100 biji dan Indeks panen yang lebih tinggi dibandingkan hasil yang diberikan oleh perlakuan arang sekam padi dan kontrol.

Jenis pupuk guano juga memberikan pengaruh paling optimal terhadap pertumbuhan dan hasil kacang hijau. Hampir semua parameter pengamatan baik parameter pertumbuhan maupun hasil tertinggi diperoleh dari pengaruh pemberian pupuk guano, kecuali berat segar brangkasan. Demikian pula pada parameter lingkungan, pupuk guano berpengaruh terhadap $\mathrm{pH}$ media yang lebih rendah (mendekati netral) dan DHL paling tinggi, yang menunjukkan bahwa unsur hara cukup tersedia bagi pemenuhan kebutuhan tanaman. Dalam kondisi seperti ini, pertumbuhan tanaman menjadi lebih baik sehingga hasil yang diperoleh pun lebih tinggi. Hal ini ditunjukan dengan hasil tertinggi yang diperoleh berupa jumlah polong, panjang polong, jumlah biji per polong, jumlah biji per tanaman, berat biji per polong dan berat 100 biji. Demikian pula indeks tertinggi dihasilkan dari pengaruh faktor tunggal arang serbuk gergaji.

\section{Simpulan}

Tidak terjadi interaksi antar perlakuan jenis biochar dan jenis pupuk organik. Jenis biochar serbuk gergaji memberikan pengaruh paling optimal terhadap pertumbuhan dan hasil tertinggi berupa berat biji per tanaman $2,60 \mathrm{~g}$. Jenis pupuk guano memberikan pengaruh paling optimal terhadap pertumbuhan dan hasil tertinggi berupa berat biji per tanaman 3,12 $\mathrm{g}$.

\section{Pustaka}

Badan Pusat Statistik (BPS). 2003. Survei Demografi dan Kesehatan Indonesia (SDKI) 2002-2003.

Bambang. 2012. Pengertian SAE. (Online) http://bambangtresnow/.blogspot .com/2012/01/pengertian-sae.html (diakses 5 Maret 2015).

Dinas Pertanian dan Ketahanan Pangan.2012. Kacang Hijau di Kabupaten Gorontalo. Gorontalo.

Gomez, K. A. dan A. A. Gomes. 1995. Prosedur Statistik untuk Penelitian Pertanian. Edisi ke 2. Jakarta:UI Press.

Ikatan Bidan Indonesia, 2012. Lima Puluh Tahun IBI - Bidan Menyongsong Masa Depan, Jakarta : PP IBI.
Nurjen, Sudiarso dan Nugroho. 2002. Peranan pupuk kotoran ayam dan pupuk urea terhadap partumbuhan dan hasil kacang hijau varietas Sriti. Agrivita 24(1): 1-8.

Scan W. 2012. Pengaruh Pemberian Trichoderma dan Pupuk Kandang Ayam Terhadap Pertumbuhan dan Hasil Tanaman Kacang Hijau (Vigna radiata, L.) Pada Tanah Alluvial di Polybag.

Supeno, A. dan Sujudi. 2004. Teknik pengujian adaptasi galur harapan kacang hijau di lahan sawah. Buletin Teknik Pertanian, 9(1): 20-22. 